Article

\title{
Evaluating the Impact of Environmental Education on Ecologically Friendly Behavior of University Students in Pakistan: The Roles of Environmental Responsibility and Islamic Values
}

\author{
Abida Begum ${ }^{1}$, Liu Jingwei ${ }^{1, *}$, Imran Ullah Khan Marwat ${ }^{2}$, Salim Khan ${ }^{3}$, Heesup Han ${ }^{4, *(D)}$ \\ and Antonio Ariza-Montes ${ }^{5}$ D \\ 1 School of Marxism, Northeast Forestry University, Harbin 150040, China; abidakhg@gmail.com \\ 2 Department of Management Sciences, International Islamic University, Islamabad 44000, Pakistan; \\ imranmarwat@gmail.com \\ 3 Institute of Business Studies, Kohat University of Science and Technology, Kohat 26000, Pakistan; \\ salim@kust.edu.pk \\ 4 College of Hospitality and Tourism Management, Sejong University, Seoul 05006, Korea \\ 5 Social Matters Research Group, Universidad Loyola Andalucía, 414004 Córdoba, Spain; ariza@uloyola.es \\ * Correspondence: liujingwei@nefu.edu.cn (L.J.); heesup@sejong.ac.kr (H.H.); Tel.: +86-451-82192162 (L.J.)
}

Citation: Begum, A.; Jingwei, L.; Marwat, I.U.K.; Khan, S.; Han, H.; Ariza-Montes, A. Evaluating the Impact of Environmental Education on Ecologically Friendly Behavior of University Students in Pakistan: The Roles of Environmental Responsibility and Islamic Values. Sustainability 2021, 13, 10188. https:// doi.org/10.3390/su131810188

Academic Editor:

Pedro Vega-Marcote

Received: 18 July 2021

Accepted: 10 September 2021

Published: 12 September 2021

Publisher's Note: MDPI stays neutral with regard to jurisdictional claims in published maps and institutional affiliations.

Copyright: (c) 2021 by the authors. Licensee MDPI, Basel, Switzerland. This article is an open access article distributed under the terms and conditions of the Creative Commons Attribution (CC BY) license (https:/ / creativecommons.org/licenses/by/ $4.0 /)$.

\begin{abstract}
With increasing global environmental problems, considerable evidence now suggests that environmental education can influence students' ecologically friendly behavior significantly. Addressing increased environmental problems requires better understanding of the relations between focused and explicit environmental education, environmental responsibility, and religious values. The current study examined the relationship between environmental education and ecologically friendly behavior, utilizing insights from resource conservation theory. The relationship between the variables mentioned above was examined to determine the mediating effect of environmental responsibility and the moderating effect of Islamic values. Through a cross-sectional approach, data were gathered from 413 university students. The data were analyzed using analytical techniques such as "structural equation modeling" and "PROCESS." The study's findings support the predicted conceptual model, indicating that environmental education was positively related to environmentally friendly behavior. Furthermore, environmental responsibility partially mediated the relationship above, whereas Islamic values positively moderated the relationships between environmental education and ecologically friendly behavior as well as between environmental education and environmental responsibility. These findings emphasize the critical role of environmental education and Islamic values in comprehending the ecological behaviors of Muslim students.
\end{abstract}

Keywords: environmental education; environmental responsibility; Islamic values; ecologically friendly behavior; Pakistani university students

\section{Introduction}

Environmental education is critical in understanding high-level ecological concerns and behaviors. Environmentally educated persons are more motivated to improve the environment because education raises awareness of the potential harm to the environment [1]. Generally, environmental education imparts a high level of information and awareness regarding environmental issues and solutions, resulting in sustainable and ecologically friendly behavior (EFB) [2,3]. Environmental education enhances understanding and sensitivity to environmental problems, broadens knowledge, and contributes to developing favorable attitudes toward ecological challenges [4]. It is believed that human behavior currently hurts the environment. Younger generations will be disproportionately affected due to current global environmental problems, which will only worsen if they are not 
adequately addressed [3,5]. As a result, it is critical to understand and improve individuals' ecological behavior. Individual responsibility grows due to environmental education, ethics, and skills required for a more sustainable and improved world. Thus, universities could play a critical role in enforcing ecologically friendly behavior and transforming societies toward environmental sustainability [6,7]. Universities have recently begun to promote pro-environmental and sustainable development through education and research by integrating sustainability into institutional agendas and fostering diverse initiatives for staff training, awareness, and development. A systematic review of a handful of research papers on the effect of education on EFB concluded that education might increase individuals' understanding of their EFB [8]. The leaders of tomorrow are being educated in universities. It is critical to provide them with ethics and environmental education so that they become psychologically empowered and their attitudes shift toward environmentally friendly behaviors, which could lead to societal sustainability $[9,10]$.

Understanding one's tendency to adopt EFB is a complicated and complex issue. Various factors affecting EFB have previously been considered, including environmental concerns, intentions, self-identity, value orientation, personal norms, etc. [11-17]. Environmental responsibility plays a critical role in enhancing ecological behaviors by imparting an individual with a sense of responsibility and motivating people to protect the environment [18]. The present study proposed that environmental education is positively related to ecologically friendly behavior directly and indirectly (via environmental responsibility). Furthermore, given the importance of Islamic values on environmental protection, such as environmental balancing, environmental awareness, and resource conservation (water, trees, etc.) [19], Islamic values were proposed as a boundary condition to the previously proposed relationships in the current study (refer to Figure 1 for the conceptual framework of the study).

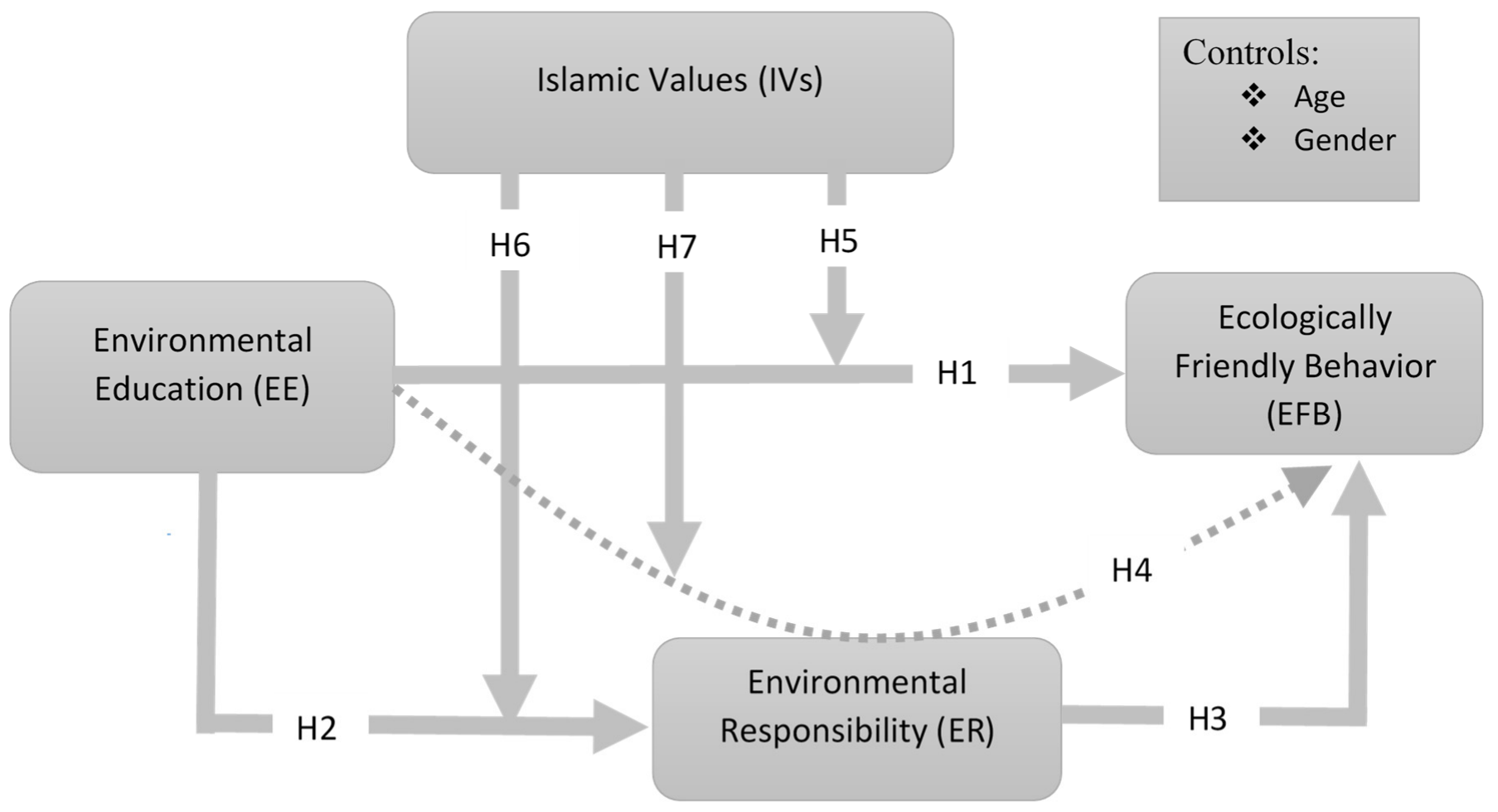

Figure 1. The theoretical framework of the study.

This study contributes to the literature in two significant ways. Firstly, the study broadens understanding of the mediating effect of environmental responsibility on the relationship between environmentally friendly behavior and environmental education. 
Very few studies have been carried out that considered environmental responsibility as the mediator between ecologically friendly behavior and environmental education [2,20]. Therefore, in this study, environmental responsibility is used as a mediator to explain the relationship between environmental education and environmentally friendly behavior. Secondly, although Islamic values are becoming increasingly important in environmental literature, attention to their role in ecologically friendly behavior is scarce [21]. This study broadens its scope to include ecologically friendly literature by proposing Islamic values as a moderator between environmental education and ecologically friendly behavior. In sum, the first aim of this study was to learn more about the relationship between environmental education and environmentally friendly behavior by looking into the mediating role of environmental responsibility. Additionally, the study sought to expand understanding of the role of Islamic values in environmentally friendly behavior.

The following section discusses the conceptual model and the study's hypotheses. Following that, the study's methodology, as well as its findings and analysis, is presented. Structural equation modeling with AMOS and SPSS software (IBM, Armonk, NY, USA) was used to test the hypotheses. Data were collected from undergraduate and postgraduate students. Finally, the authors discuss their findings and conclusions and make future recommendations.

\section{Literature Review and Hypotheses Development}

\subsection{Environmental Education and Ecologically Friendly Behavior}

Environmental education (EE) is education about, from, and for the environment [22]. Ecological knowledge and understanding are developed through EE, which also provides potential skills that benefit the environment. Education from the environment can be accomplished by utilizing the outdoors as a learning resource. In contrast, EE fosters awareness and a sense of responsibility for the environment, positively affecting attitudes and behaviors toward a green ecological lifestyle [23]. Environmental education is widely recognized as a critical component of biodiversity conservation efforts [24]. Increased knowledge and environmentally conscious behavior are two of the most debated educational outcomes in the literature. Numerous studies have been conducted on the return of education $[11,19,23]$.

Environmental education is critical in combating ecological problems, aiming to protect and conserve the planet's resources for a healthy and prosperous life. The impact of EE on EFB has been extensively researched all over the world. The relationship varies according to region, religion, culture, and various other factors [3,25]. Although most studies found a positive relationship between EE and EFB, some studies suggested that a high level of environmental education does not always reflect environmentally friendly behavior [26]. For example, Ek and Soderholm [27] revealed no correlation between a high level of education and the choice to use green electricity.

Furthermore, Ayalon et al. [28] found no evidence that education impacted recycling behavior. Wessells et al. [29] found that consumers with a high level of education were not more likely to purchase eco-labeled seafood. Finally, Grafton [30] discovered a negative correlation between water conservation and a high level of education.

On the other hand, numerous studies have discovered that EE increases individuals' awareness of the environment and motivates them to engage in ecologically friendly behaviors in various contexts [31,32]. For instance, there is existing literature demonstrating that education promotes recycling behavior [33-35]. Other researchers discovered that education influenced people's food choices, with more people opting for environmentally friendly options due to their education. For example, an environmentally savvy individual typically prefers eco-friendly shopping [36,37]. Berl et al. [38] found that highly educated individuals practice water conservation. Similarly, other studies indicate that educated individuals exhibit energy-saving behavior [12,39]. Additionally, it was discovered that education is associated with a higher rate of EFB. For instance, Rowlands et al.'s [40] study 
discovered that individuals aware of green electricity would emphasize and advocate for increased production of eco-friendly electricity.

Moreover, De Silva and Pownall [41] found that college students were willing to put their financial well-being on the line to improve environmental quality. A study by Xiao et al. [42] demonstrated that well-versed environmental education students have environmental awareness. Furthermore, Torgler and García-Valiñas [43] revealed that informal education through print, electronic, and social media, in addition to formal environmental education in universities, contributes to EFB.

Aside from the existing literature on the EE-EFB relationship, according to Mitchell and Hodson [44], EE can also be thought of as a stand-alone resource that provides additional support to EFB; the phenomenon follows the conservation of resources (COR) model [45]. The COR model's central tenet is that people should strive to create, protect, retain, and maintain resources. Resources refer to the objects, individual characteristics, energies, or conditions that individuals value or that serve to achieve these objects, individual characteristics, energies, or conditions [45]. Examples of resources include self-esteem [46], learned resourcefulness [47], organizational behavior, behavioral medicine, social work, education, and employment [48]. The model indicates that those with a reliable resource pool are the most "resource secure," having developed a substantial reservoir of resources [49]. Because education is such a valuable and high-quality resource, it will positively influence people's attitudes toward resource conservation through EFB (i.e., gain of resource). As the preceding discussion implies that EE will influence an individual toward EFB, we propose that environmental education is positively associated with ecologically friendly behavior.

\subsection{The Mediating Effect of Environmental Responsibility}

Environmental responsibility (ER) is defined in this study as a sense of personal obligation toward the environment or sentiments of responsibility to take action to avoid negative environmental consequences. Responsibility has been investigated as a complex notion that has been quantified in terms of moral duty, responsibility sentiments, or ascription of responsibility (i.e., responsibility judgment) regarding the environment as a whole or a specific environmental issue [50]. Environmental responsibility is comparable with moral duty, which is determined by a person's responsible judgment, sentiments, and level of knowledge of the implications of a specific behavior [50]. ER has attracted a lot of attention, and environmentally friendly production has become more prevalent [51]. Han et al. [52] defined ER as sentiments of personal responsibility to engage in a particular action that is beneficial to society and the environment. According to Stern, environmental responsibility is an essential characteristic that may contribute to personal norms, and personal norms have a substantial impact on an individual's decision to engage in pro-environmental actions [53]. Researchers, especially in academies, retain a strong interest in what fosters and drives ER. ER is thought to be crucial in promoting EFB. ER plays a critical role in assisting governments and universities in developing environmental policies and businesses in mitigating risk, increasing environmental efficiency, and fostering societal resilience [54]. The growth of the perception of responsibility significantly increases a person's readiness to engage in pro-environmental behavior [55]. Clark et al. [56] also stated that environmental responsibility enables individuals to act for environmental protection. Zhu et al. [57] also revealed that different levels of responsibility influence one's conservation intention. ER has the capacity to persuade both individuals and organizations that they are accountable for generating different environmental issues as a result of their activities and that they should change their everyday practices to avoid negative effects [58]. ER is greatly personal in nature, which might result from both moral obligations to communities and/or nature and personal emotions of duty as a result of societal pressures [59]. It has been found that ER is a very effective tool to motivate people toward green actions taking inspiration from environmental education. However, research shows that considerable heterogeneity exists in attitudes in different sectors toward personal environmental responsibility. It has been found that some people take better care of the environment and 
their home and workplace than at tourist scenic spots they may visit [60]. Similarly, in terms of socio-demographic, psychological, and environmental behaviors, Dolnicar and Leisch [61] discovered substantial disparities between two tourist groups (high vs. low environmental responsibility).

However, the relationship between environmental responsibility and environmental education has not been studied extensively in the context of pro-environmental behavior. Environmental responsibility has frequently been overlooked as a major predictor that may encourage suitable environmental activities through environmental education and Islamic values lessons in the educational institutes. Diverse responsibility characteristics in students may be further studied to understand better what kind of EFB they like. Such observations would help determine the merits of various environmental education programs that can determine how students will be encouraged to be environmentally responsible.

Therefore, this study emphasized environmental education and Islamic values in creating ER feeling in the students. This work aimed to thoroughly review the available information on ER and compare its mediating role between EE and EFB. As mentioned previously, ER has been used as a mediating factor in several studies looking at psychological, social, and long-term environmental variables. Based on the literature cited above and the concept of resource caravans proposed by conservation of resource theory, we believe that environmental responsibility can mediate EE and EFB [48]. The EE resource pool is in a position to orchestrate environmentally friendly behaviors [62]. We believe that by utilizing the EE resource on students, another resource is created in environmental responsibility, which results in resource conservation through eco-friendly behaviors and sustainable lifestyles. As a result, environmental responsibility appears to act as a mediator between EE and EFB.

Based on the preceding discussions, we propose that environmental responsibility mediates the positive relationship between ecologically friendly behavior and environmental education.

\subsection{The Moderating Effect of Islamic Values}

Theoretically, values have the potential to motivate and influence behavior [63]. Individuals' and societies' values and attitudes are shaped by religion, which guides how to live [64]. These values and attitudes shape community and society's behaviors. Islam instills in its adherents the values of sustainability, altruism, and resource conservation [21]. Those who adhere to religions in their true spirit and possess a high level of altruism are more likely to be actively involved in environmentally sustainable behaviors [65]. Islamic values are distinct from personal values. They are ethical principles derived from religious traditions founded on scriptures, such as the Quran and Hadith for Muslims, and ingrained in their lives. Religious values are frequently debated as a way of analyzing their impact on consumer behavior. Religious values significantly impact a person's way of life, thoughts, and habits, among other things. As a result, there has been a great deal of discussion about the impact of religious values on human behavior for the past few decades. When dealing with a religious country where the majority of the population adheres to the same religion, as in the case of Pakistan, where Islam is the official national religion, the significance is increased even further [66].

Their religious values heavily influence consumers' green purchasing decisions. Considering the profound impact of religiosity, several authors have proposed considering religious value's supremacy in the ecological green environment. Additionally, it was observed that among Muslims, their level of religiosity influences their behavior to spend sensibly and shop sustainably [67]. Additionally, religious values help individuals make purchasing decisions based on resource conservation, principles of suitability, and environmental stewardship, such as adopting sustainable clothing consumption [64].

Ecologically friendly behavior results in the protection of the environment's natural resources. In the literature, those who exhibit ecologically friendly behavior are referred to as green consumers [68]. Additionally, prior research indicates that religious values 
positively influence green consumer behavior that protects the world's natural ecological cycles. Most previous studies developed a religiosity scale for Christianity to assess its impact on ecological behaviors [69]. On the contrary, Razak et al. [70] examined the relationship between ecologically friendly behavior and Islamic religiosity and discovered a positive and significant correlation. Islam and Chandrasekaran [19] assert that more religious Muslim consumers make greater efforts to protect the natural environment than less religious Muslim consumers. Islamic values introduce the concepts of sustainability and balanced action, emphasizing the importance of not consuming more than one's needs and contributing to the well-being of others [71]. Islam teaches sustainability, impartiality, balanced actions, and judicial actions to safeguard the ecological system. According to Islam, humans do not own the Earth's natural resources. Additionally, Islam emphasizes the protection of natural resources through prudent resource consumption [67].

Previously conducted research established a link between religion and consumer behavior [72]. Religion instills values that serve as guiding principles for the individual's life. However, religion, which is highly personal and depends on an individual's level of piety or commitment to their religion, affects consumer behavior. Green consumerism is a matter of ethics and morality [73]. Religious beliefs assist believers in determining the appropriateness or inappropriateness of their behavior. Ideally, Islamic values could be thought of as a predictor of consumer behavior. Islamic values affect human behavior directly or indirectly [74]. According to Shariah principles, all Muslims are obligated to safeguard the Islamic faith, human life, property, and the mind [75]. Intentional harm to the natural environment and resources is a form of corruption that Islam forbids. In Islamic teachings, human beings are made "Khalifas" or Caliphs of the Earth and entrusted with looking after and caring for the Earth.

However, some other schools of thought, e.g., Koehrsen [76], synthesizes existing research about climate change and Muslim communities. He found out that there is no uniform interpretation of climate change among Muslims. Muslims have developed several approaches to climate change based on their understanding of Islam. A small group of Muslim environmentalists engages in public campaigns to raise awareness about climate change, minimize carbon emissions through sociotechnical transition initiatives, and disseminate pro-environmental Islamic interpretations. However, it is unclear to what degree these efforts result in larger changes in the daily activities of Muslim communities and organizations. Contributions to this field of study are frequently theoretical, emphasizing only theological and normative elements of Islam. Comparative studies are needed to explore the role of Muslim environmentalism in climate change mitigation and adaptation on a local and global scale, taking into account regional and theological distinctions among Muslims. Among others, Taylor et al. [77] provided a thorough examination of the harmful environmental consequences of "Judeo-Christian" beliefs, as well as later assertions that the world's major faiths are becoming more ecologically friendly.

The Islamic faith places a high value on environmental preservation. The Quran encourages believers to appreciate Allah's gifts as well as the material aspects of life. The term "believers" refers to those who maintain their focus on the aforementioned important factors. There is a lot of evidence in Islamic teachings that emphasize the importance of environmental protection. For example, some of the verses in the Quran state:

"Walk on the Earth in humility (Quran, 18:63 [78]). Then We appointed you viceroys in the Earth after them, that We might see how ye behave (Quran 10:14)."

"And when he turneth away (from thee) his effort in the land is to make mischief therein and to destroy the crops and the cattle; and Allah loveth not mischief (Quran 2:205)."

"Do no mischief on the Earth, after it hath been set in order (Quran, 7:56)."

Muslims are obligated to protect the Earth in all ways, as Islam considers the Earth a sacred and holy place. As Muslims, we can pray anywhere on the planet, and in addition 
to water, certain other elements on the planet can be used to purify even the most egregious impurities. As stewards of the Earth, we must protect the planet as a mosque, and it is each individual's responsibility to care for the Almighty God's entire creation. The earlier literature shows that Islamic values are a critical factor in the ecological behavior of Muslims. The moderating role of Islamic values in this context has received limited attention. As a result of the preceding discussion, it has been hypothesized that Islamic values will act as a moderating factor in the relationship between EE and EFB. In line with these arguments, we believe that Islamic values are a personal resource that, if invested in the EE and ER resource pools, will result in green ecological behaviors and, as a result, additional resources. This assumption corresponds to the COR's viewpoint [48]. Given these considerations, we believe that students who are provided with EE and have strong Islamic values will be more effective in protecting and conserving the environment. Thus, we propose that Islamic values play a moderating role in our study.

\subsection{Hypotheses}

Based on the aforementioned arguments and evidence, we established these hypotheses:

Hypothesis 1 (H1). Environmental education is positively related to ecologically friendly behavior.

Hypothesis 2 (H2). Environmental education is positively related to environmental responsibility.

Hypothesis 3 (H3). Environmental responsibility is positively related to ecologically friendly behavior.

Hypothesis 4 (H4). Environmental responsibility mediates the positive relationship between environmental education and ecologically friendly behavior.

Hypothesis 5 (H5). The direct positive relationship between environmental education and ecologically friendly behavior is expected to be significant for those who are high in Islamic values.

Hypothesis 6 (H6). The direct positive relationship between environmental education and environmental responsibility is expected to be significant for those who are high in Islamic values.

\section{Methodology}

\subsection{Sampling Procedure}

Universities produce future leaders, decision makers, and scholars in the political, economic, and social sectors, and thus university students were chosen as the study's target population. Furthermore, the data gathered from students came from homogeneous groups with small random errors. Because they were studying much literature on these issues in their curriculum, university students were more concerned about the ecological wellbeing of nature [2,3]. Data were gathered from Peshawar's public and private universities (Capital of Khyber Pakhtunkhwa Province, Pakistan). According to the Pakistan Bureau of Statistics, Peshawar is Pakistan's sixth-largest city, and it is currently dealing with serious environmental issues. Furthermore, very little research is conducted throughout the country, particularly in Peshawar. The data were gathered from a random sample of students at six universities (three public and three private). Agricultural University Peshawar, University of Peshawar, and Islamia College University Peshawar were chosen as public sector universities. City University of Science and Information Technology Peshawar, Sarhad University of Science and Information Technology Peshawar, and CECOS University Peshawar were among the private universities visited. Before beginning the data collection, the heads of the department and the class in charge were approached for permission. Prospective students were given a brief presentation in the classroom about the research survey's goals and nature. In addition, the questionnaire survey included a cover letter stating that the purpose of the study was solely for research purposes and that the respondents would be kept anonymous and confidential. Students were also told that taking part in the survey was completely voluntary and that they could opt out at any point during the data collection process. Students were given sufficient time to respond to and complete a pen and pencil survey questionnaire, which they then returned anonymously 
to the researchers in envelopes. Five hundred surveys were distributed, and 452 were returned, resulting in a response rate of $90.4 \%$. Thirty-nine questionnaires were invalid due to incompleteness or careless responses, leaving 413 usable questionnaires [79]. The sample consisted of 265 male respondents (64.1\%) and 148 female respondents (35.9\%). Of all valid respondents, $79.1 \%$ were undergraduates, while $20.9 \%$ were postgraduates.

\subsection{Instruments}

The measures used in this study were adapted from previous research and slightly modified to meet the requirements of the current study. The variables were rated on a five-point Likert scale ranging from 1 to 5, with 1 indicating "strongly disagree" and 5 indicating "strongly agree." The scale for environmental education consisted of two parts having eight items-formal and informal education. The former scale was derived from a study conducted by Pérez-Rodríguez et al. [80], whereas the latter was derived from a study conducted by Varela-Candamio et al. [81]. The environmental responsibility scale was constructed using five items adapted from Wang et al. [82], which were previously tested by [83] in the context of environmental responsibility and pro-environmental consumer behavior. Islamic values can be measured by the religiosity of individuals toward the basic Islamic principles. For this research, the religiosity scale was modified from Plante [84]. The dimensions for Islamic values are related to the Islamic faith and religious action; as a result, it is easier to adapt and is thought to be superior to other scales. A 14-item scale was adapted from Kaiser et al. [85]. It was used to assess ecologically friendly behavior. Cronbach's coefficients $(\alpha)$ were calculated for all scales that fell within the acceptable range. When it comes to university students, gender and age are the most influential variables [86]. Because the literature indicates that these variables significantly impact students' green behavior, we investigated their impact as control variables in this study.

\subsection{Analytical Approach and Construct Validity}

Because data were collected from individual participants in a cross-sectional study [87], the possibility of common method variance (CMV) was a concern. Harman's one-factor test was used to evaluate CMV [88]. All of the main constructs are entered into a principal component factor analysis in this test. When a single factor emerges from the analysis or when a single general factor accounts for the majority of the covariance in the interdependent and dependent variables, there is evidence of CMV. The results indicate that five factors with an eigenvalue greater than 1 explained $64.4 \%$ of the variance, whereas the highest single factor, representing EE, explained $25.9 \%$ of the variance. This indicates that CMV was not a significant issue in this study's data.

Anderson and Gerbing [89] recommended that two-step analytical procedure was used to examine the proposed model using SPSS and AMOS versions 23 (IBM, Armonk, NY, USA). That is, the model variables were first analyzed using confirmatory factor analysis (CFA) and maximum likelihood estimation to determine the distinctness of the primary study constructs before moving on to structural equation modeling (SEM) [90]. These methods are effective statistical tools for examining a priori hypotheses about relationships between observed and latent variables and testing association among latent constructs [91].

All the study variables were found to have a significant correlation with each other at the 0.01 level. The latent factors were also evaluated for reliability and validity concerns. The composite reliability of all the study variables was above 0.7 , thereby showing excellent internal reliability. Similarly, the average variance extracted (AVE), a measure of construct validity, of all the study variables was above the threshold value of 0.5 [92], which means no issues regarding the construct validity of all the study variables. Finally, all the study variables were evaluated for discriminant validity, as per criterion [92]; the square rooted AVEs (which are given diagonally with bold letters) of all the study variables were more extensive than the correlation between them. This means that all the study variables are significantly differentiated from each other. See Table 1 for descriptive, reliability, and validity estimates of the study variables. 
Table 1. Descriptive, correlation, reliability, and validity estimates.

\begin{tabular}{ccccccccc}
\hline Variables & M & SD & CR & AVE & EE & ER & EFB & IV \\
\hline EE & 4.6 & 1.50 & 0.95 & 0.69 & 0.83 & - & - & - \\
ER & 4.5 & 1.49 & 0.83 & 0.62 & $0.51^{* *}$ & 0.79 & - & - \\
EFB & 4.4 & 1.35 & 0.95 & 0.57 & $0.39^{* *}$ & $0.36^{* *}$ & 0.75 & - \\
IV & 4.0 & 1.20 & 0.96 & 0.70 & $0.23^{* *}$ & $0.32^{* *}$ & $0.41^{* *}$ & 0.83
\end{tabular}

Note: ${ }^{* *} p<0.01, \mathrm{EE}=$ environmental education, IV = Islamic values, ER = environmental responsibility, $\mathrm{EFB}=$ ecologically friendly behavior, $\mathrm{M}=$ mean, $\mathrm{SD}=$ standard deviation, $\mathrm{AVE}$ = average variance extracted, $\mathrm{CR}=$ composite reliability.

\section{Results}

\subsection{Measurement Model Evaluation}

The items for 413 responses were loaded on their respective latent factors through confirmatory factor analysis (CFA). The model provided a good fit to the data $\left(\chi^{2}=685.87\right.$, $\left.\chi^{2} / \mathrm{DF}=1.23, \mathrm{CFI}=0.98, \mathrm{TLI}=0.98, \mathrm{RMESA}=0.03, \mathrm{SRMR}=0.03\right)$. This model was compared against several other alternative models. In the first alternative model, the items measuring the Islamic values and ecologically friendly behavior were loaded on a single latent factor. The resulting model did not fit well to the data because the chi-square value increased by 2479 , CFI and TLI, respectively, decreased by 0.25 and 0.27 , and RMSEA and SRMR increased by 0.08 and 0.09 , respectively. In the second alternative model, the items of three latent factors-environmental education, ecologically friendly behavior, and Islamic values-were merged into one factor. The resulting model showed a further decline in model fit as chi-square increased by 1959.1, CFI and TLI decreased by 0.22 and 23 , respectively, and RMSEA and SRMR increased by 0.04 and 0.05 . In the final alternative model, all the items were loaded on a single latent factor. The resulting model showed the worst fit to the data among all the available models as chi-square further increased by 292.64. At the same time, TLI and CFI decreased by 0.03 while RMEA increased by 0.01 . Comparing the baseline model against different models showed that all the tested measures appropriately measure the respective latent factors. The measurement model comparison test is summarized in Table 2.

Table 2. Measurement model comparison test.

\begin{tabular}{ccccccc}
\hline Model & $\chi^{2}$ & $\chi^{2} /$ DF & CFI & TLI & RMSEA & SRMR \\
\hline Baseline Model & 637.781 & 1.31 & 0.98 & 0.98 & 0.03 & 0.03 \\
3-factor Model & 3117.65 & 5.59 & 0.73 & 0.71 & 0.11 & 0.12 \\
2-factor Model & 5076.75 & 9.08 & 0.51 & 0.48 & 0.15 & 0.17 \\
1-factor Model & 5369.39 & 9.58 & 0.48 & 0.45 & 0.16 & 0.17 \\
\hline
\end{tabular}

\subsection{Structural Equation Model Path Analysis}

The analysis was conducted in two steps. In the first step, the mediation model was tested using structural equational modeling (SEM). In the second step, the PROCESS macro was used to analyze the moderating effect.

The fit statistics of the SEM model were $\left(\chi^{2}=456.10, \chi^{2} / \mathrm{DF}=1.33, \mathrm{CFI}=0.98\right.$, TLI $=0.98$, RMESA $=0.03$, SRMR $=0.03)$, implying that the model had a good fit $[90,93]$. AMOS was used to analyze the direct relationship between all the study variables using the structural equation model. All the linear relationships were observed in a single structural model. The control variables (age and gender) did not significantly influence the estimates. Their impact was tested on independent (environmental education) and dependent variables (ecologically friendly behavior). However, it is noteworthy that the insignificance of controls did not deteriorate our main model's results. The results depicted in Table 3 show the outcomes of the structural equation model path analysis. 
Table 3. Structural model estimates.

\begin{tabular}{ccccc}
\hline Effects & $\boldsymbol{\beta}$ & SE & CR & Significance Level $(p)$ \\
\hline Age $\rightarrow$ EE & 0.005 & 0.02 & 0.307 & 0.75 \\
Gender $\rightarrow$ EE & -0.009 & 0.13 & -0.06 & 0.95 \\
Gender $\rightarrow$ EFB & 0.21 & 0.12 & 1.68 & 0.09 \\
Age $\rightarrow$ EFB & -0.004 & 0.01 & -0.28 & 0.77 \\
EE $\rightarrow$ EFB & 0.28 & 0.07 & 4.13 & $<0.001$ \\
EE $\rightarrow$ ER & 0.55 & 0.06 & 9.43 & $<0.001$ \\
ER $\rightarrow$ EFB & 0.27 & 0.07 & 3.66 & $<0.01$ \\
\hline
\end{tabular}

Note: $\mathrm{SE}=$ standard error, $\mathrm{CR}=$ critical ratio.

The study's analytical results reveal that the students' environmental education significantly influenced their environmentally friendly behavior $(\beta=0.28, p<0.001)$, providing support to H1. Moreover, the results of the study show that students' environmental education had a significant effect on their environmental responsibility $(\beta=0.55, p<0.001)$, and their environmental responsibility was further found to significantly influence ecologically friendly behavior ( $\beta=0.27, p<0.01)$, leading us to accept $\mathrm{H} 2$ and $\mathrm{H} 3$. The significance of both direct and indirect paths indicated partial mediation.

\subsection{Mediating Effect of Environmental Responsibility}

Indirect effect of environmental responsibility was estimated using the user-defined estimand in the above-discussed structural model. The indirect effect was found significant $(\beta=0.14, p<0.01, \mathrm{CI}[\mathrm{L}=06, \mathrm{U}=0.24])$, supporting $\mathrm{H} 4$. Therefore, environmental responsibility significantly mediated the relationship between environmental education and ecologically friendly behavior. That is, environmental education had a significant impact on ecologically friendly behavior indirectly through environmental responsibility.

\subsection{Moderated Mediation}

In hypotheses $\mathrm{H} 5$ and $\mathrm{H} 6$, the current study expected that Islamic values would moderate environmental education's direct and indirect effects on ecologically friendly behavior via environmental responsibility. We examined the moderated mediation hypotheses with the PROCESS macro v.3.0 (Table 4), and the results are provided in Figure 2. The results show a significant positive interaction of environmental education and Islamic values on ecologically friendly behavior $(\beta=0.08, p<0.01)$. Direct effect of EE was larger and highly significant at higher values (+1 SD) of Islamic religiosity (Estimate $=0.31,95 \% \mathrm{CI}$ $\mathrm{CI}[\mathrm{L}=0.19, \mathrm{U}=0.43])$. Therefore, the direct positive relationship between environmental education and ecologically friendly behavior is expected to be significant for those who are high in Islamic values. Meanwhile, this effect was low and non-significant at lower values of Islamic religiosity $(-1 \mathrm{SD})($ Estimate $=0.09,95 \% \mathrm{CI}[\mathrm{L}=-0.03, \mathrm{U}=0.23])$ as the zero falls between the upper and lower bounds of the confidence interval. See Table 4 for the result.

Table 4. PROCESS model 8.

\begin{tabular}{|c|c|c|c|c|}
\hline \multirow{2}{*}{ Effects } & \multirow{2}{*}{$\beta$} & \multirow{2}{*}{ SE } & \multicolumn{2}{|c|}{ Percentile $95 \%$ CI } \\
\hline & & & Lower Bound & Upper Bound \\
\hline \multicolumn{5}{|c|}{ The conditional direct effect at low, medium, and high Islamic values } \\
\hline Low Islamic values $(-1 \mathrm{SD})$ & 0.07 & 0.07 & -0.03 & 0.23 \\
\hline Medium Islamic values (0) & 0.21 & 0.05 & 0.11 & 0.30 \\
\hline High Islamic values (+1 SD) & 0.31 & 0.06 & 0.19 & 0.43 \\
\hline \multicolumn{5}{|c|}{ The conditional indirect effect at low, medium, and high Islamic values } \\
\hline Low Islamic values $(-1 \mathrm{SD})$ & 0.05 & 0.03 & 0.02 & 0.11 \\
\hline Medium Islamic values (0) & 0.06 & 0.02 & 0.03 & 0.11 \\
\hline High Islamic values (+1 SD) & 0.10 & 0.02 & 0.01 & 0.10 \\
\hline
\end{tabular}




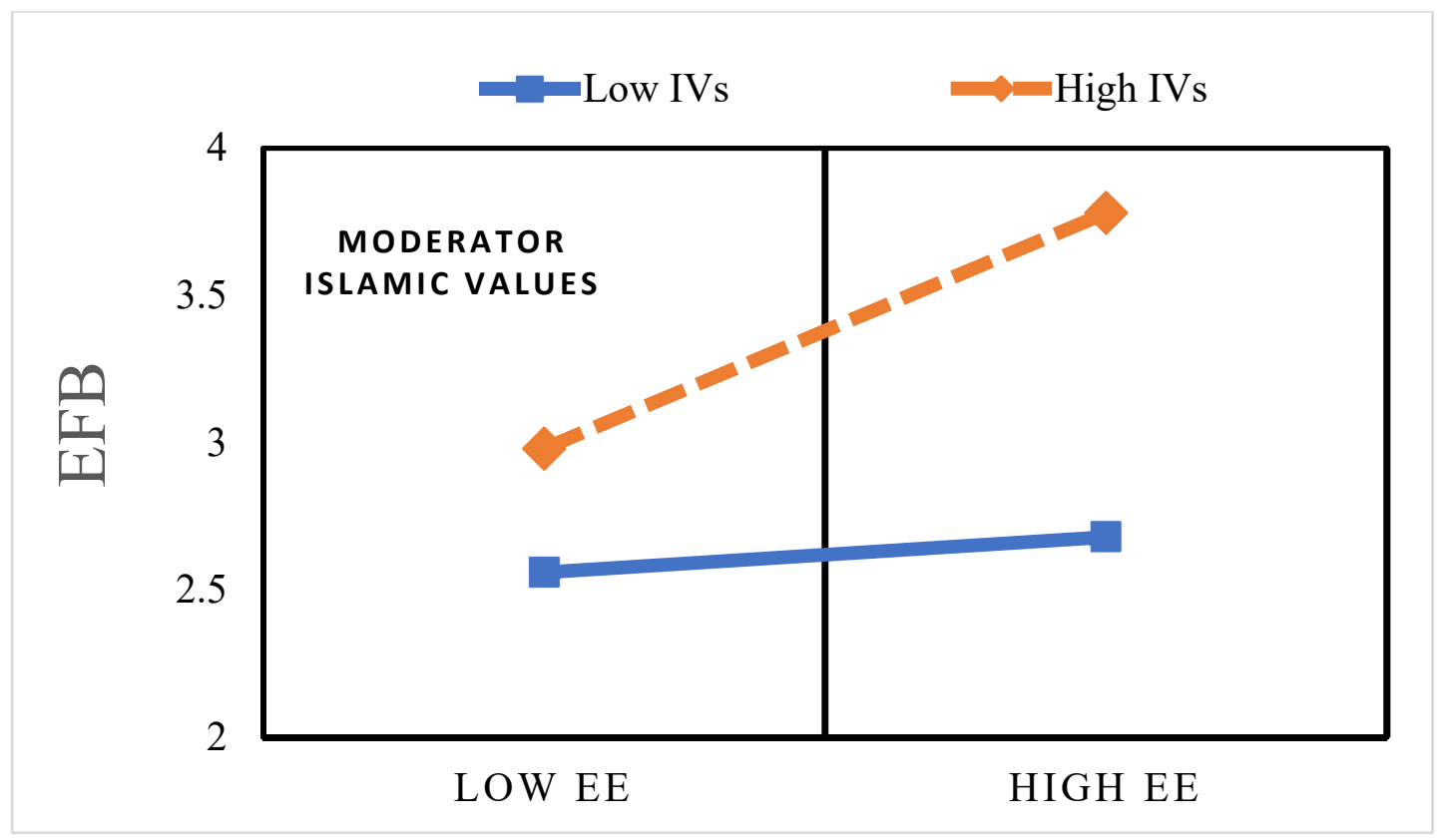

Figure 2. Ecologically friendly behavior (EFB) as a function of environmental education (EE) and Islamic values (IVs).

Similarly, the indirect effect of environmental moral education on environmentally friendly behavior via environmental responsivity was also tested. It was found that the indirect effect of environmental moral education on environment-friendly behavior was larger and significant (Estimate $=0.10,95 \% \mathrm{CI}[\mathrm{L}=0.01, \mathrm{U}=0.10]$ ) at higher values of Islamic religiosity ( $+1 \mathrm{SD})$. Meanwhile, this effect was smaller and weaker (Estimate $=0.05$, $95 \%, \mathrm{CI}[\mathrm{L}=0.02, \mathrm{U}=0.11]$ ) at lower values of Islamic religiosity. Hence Hypothesis 6 was supported.

\section{Discussion}

The current study sought to determine the relationship between university students environmental education and their propensity for ecologically friendly behavior, with the mediating effect of environmental responsibility and the moderating effect of Islamic values. The findings indicate that environmental education is positively and directly related to ecologically friendly behavior. Additionally, the study established that environmental responsibility mediated the positive relationship between environmental education and ecologically friendly behavior to a degree. Furthermore, it was established that Islamic values acted as a positive moderator. Students with a high level of Islamic values behaved more environmentally friendly than those with a lower level of Islamic values. Similarly, there was a strong link between environmental education and ecologically friendly behavior among students with high environmental responsibility and vice versa.

This study is critical in understanding how environmental education contributes to the promotion of pro-environmental or ecological lifestyles. There is a shortage of research on the effect of environmental education on ecological behavior through environmental responsibility. Our findings indicate that environmental education, directly and indirectly, motivates students toward green lifestyles via environmental responsibility mediation. This result supports previous findings that environmental education strengthens students' connections to nature and motivates them to a green lifestyle [7,35]. Similarly, Otto and Pensini [94] discovered that nature-based environmental education promotes environmentally friendly behavior. Ballantyne and Packer [95] discovered that when students learn about natural environment protection, their attitudes toward the environment, desires, and behaviors change. Environmental education has positively affected ecologically friendly behavior; consequently, educational institutions can incorporate more environmental education materials to promote ecological behavior. Islamic values promote environmental 
education and provide guidelines for behaving ecologically and conserving natural resources, providing a long-term approach to green behavior. As a whole, environmental education is a very effective way of promoting green ecological lifestyles because it empowers students to take responsibility for their actions in relation to the environment.

The current study demonstrated that environmental responsibility partially mediates the relationship between environmental education and ecologically friendly behavior; thus, it is critical to empower students to protect and conserve nature, as well as to act environmentally friendly. The concept of environmental responsibility imparts a sense of care. Individuals with a strong sense of environmental responsibility believe they have a greater role in protecting nature. As a result, they will be more receptive to engaging in ecologically friendly behavior. This study's critical contribution is that, while prior research has primarily focused on many other mediators between environmental education and ecologically friendly behavior $[5,20,96]$, this study, using conservation of resource theory, suggests that environmental education promotes environmental responsibility as a resource gain for students, increasing their environmentally friendly behavior. Thus, contributing to the theoretical development of the literature, this study demonstrates that environmental responsibility can be incorporated into the COR theory as a predictor of environmentally friendly behavior. This finding is consistent with previous research that claimed environmental responsibility influences ecologically friendly behavior [73,97]. According to the study, environmental responsibility motivates ecologically friendly behavior. These findings suggest that environmental responsibility gives people the sense to realize environmental issues they care about and motivates them to live a greener lifestyle, such as conserving water and electricity. Caravan et al. [60] found that cities with tourism as a primary industry paid more attention to similar ER activities. ER activities include efficient use of goods and natural resources; recycling, reuse, and waste management; environmental information transparency; and atmospheric governance [97,98]. Adoption of ER requires numerous environmental stakeholders, including the media, producers, customers, and states [97]. As a result, stakeholder engagement is widely regarded as a primary factor in ER. These studies illustrate the interdisciplinary and multidimensional nature of ER science. In general, this study's findings indicate that students' environmental responsibility is an effective tool for promoting green ecological behaviors.

Additionally, this study examined the moderating effect of Islamic values on ecologically friendly behavior. Islamic values were found to act as a moderator in the relationship between independent and dependent variables. The findings indicate that their religious values influence Muslims' ecological behavior. The practice of religious values is highly individualistic in nature. As a result, adapting behavior to religious instructions is also dependent on the individual's religious commitment. The study also established that individuals with a high level of religious commitment are more environmentally conscious and vice versa. Another important contribution of the research is that it expands the role of religion in ecologically friendly behavior. According to the study, students' Islamic beliefs about the environment are found to reinforce the role of environmental education in promoting ecologically friendly behavior. Our findings are also supported by previous research. For example, Djallela et al. [74] discovered that Muslims consume moderately due to resource conservation instructions. Religious consumers are also reported to be less greedy and selfish and more selfless, implying that they are more involved in sustainable and better environmental deeds. Mohammad and Som [99] also reported similar findings; they concluded that religiosity plays a critical role in developing sustainable green consumer behavior. Rice [21] believed that religiosity does affect the environmental behavior of consumers. The current study's findings confirm that Islamic values have a positive moderating effect on green ecological lifestyles. However, it is worth noting that religious values are highly individual in nature, with each individual's religiosity being quite distinct from the next [68]. 


\section{Limitations and Future Directions}

There were a few limitations in the current study that could be addressed in future research. Our study's scope was limited in terms of the society's targeted population, which could be expanded by including working professionals, housewives, and adults from various walks of life. The current study focused exclusively on university students, a very small proportion of the population; additionally, their behavior may be influenced in real life by the lifestyles of ordinary individuals. Additionally, people's green ecological behavior patterns at various stages of life and professions can be compared in the future, yielding some very positive results. The current study's findings can be compared to those from other parts of the world with diverse religions and cultures. This will aid in comprehending cultural and behavioral differences in the global adoption of green ecological behaviors.

One of the study's limitations was that the model was tested using Islamic values for Muslims; as a result, the model can only be applied to a subset of the population. Furthermore, the current study's findings are based on cross-sectional data, making causal inferences more difficult. Future researchers might find it more useful to examine the interplay between the study variables using a longitudinal design. The experimental research approach required for measuring environmental responsibility is missing in the current study [100]. Although the COR theory can be extended for this study, additional research is required to test the COR theory on the environmental-responsibility-based reinforcement process in green ecological lifestyles by incorporating additional antecedents into the proposed theoretical model.

\section{Conclusions}

In conclusion, this study demonstrated the critical role of environmental education, including formal and informal education, in developing students' ecologically friendly behaviors. Environmental education creates a sense of environmental responsibility in the context of the Islamic values code of conduct, which also prohibits its followers from causing environmental damage. The current research findings align with previous research, namely that environmental education guides students to adopt environmentally friendly behaviors [101-104]. This study found that students felt environmental responsibility by environmental education and tended to engage in eco-friendly behaviors. Environmental education guides students to adopt environmentally friendly behaviors.

Additionally, Islamic values contribute to students' development of ecologically friendly behaviors. Students with a high level of Islamic values were found to live more environmentally friendly lifestyles than those with a low level of Islamic values. As a result, it is suggested that higher institutions should promote both formal and informal environmental education to foster green and sustainable behavior. Our findings also encourage higher education institutions to consider how they might encourage religious values in ways that are legally and culturally appropriate and could enhance ecologically friendly behavior. This conclusion is also supported by prior research indicating that environmental education results in environmentally friendly behaviors [2,3]. Additionally, environmental education must emphasize the dissemination of information, the promotion of ecocentrism, and a desire to conserve nature.

Author Contributions: Formal analysis, I.U.K.M., A.B.; funding acquisition, A.B., L.J., I.U.K.M., H.H. and A.A.-M.; investigation, L.J.; project administration, S.K.; supervision, H.H. and A.A.-M.; writing—original draft, A.B.; writing—review and editing, L.J., I.U.K.M. All authors have read and agreed to the published version of the manuscript.

Funding: This research received no external funding.

Institutional Review Board Statement: Not applicable.

Informed Consent Statement: Not applicable. 
Data Availability Statement: The data presented in this study are available on request from the corresponding author. The data are not publicly available due to privacy.

Conflicts of Interest: The authors declare that there is no conflict of interest.

\section{References}

1. Ahmed, Z.; Asghar, M.M.; Malik, M.N.; Nawaz, K. Moving towards a sustainable environment: The dynamic linkage between natural resources, human capital, urbanization, economic growth, and ecological footprint in China. Resour. Policy 2020, 67, 101677. [CrossRef]

2. Kim, M.-S.; Kim, J.; Thapa, B. Influence of Environmental Knowledge on Affect, Nature Affiliation and Pro-Environmental Behaviors among Tourists. Sustainability 2018, 10, 3109. [CrossRef]

3. Janmaimool, P.; Khajohnmanee, S. Roles of Environmental System Knowledge in Promoting University Students' Environmental Attitudes and Pro-Environmental Behaviors. Sustainability 2019, 11, 4270. [CrossRef]

4. Yucedag, C.; Kaya, L.G.; Cetin, M. Identifying and assessing environmental awareness of hotel and restaurant employees attitudes in the Amasra District of Bartin. Environ. Monit. Assess. 2018, 190, 60. [CrossRef]

5. Pachauri, R.K.; Allen, M.R.; Barros, V.R.; Broome, J.; Cramer, W.; Christ, R.; Church, J.A.; Clarke, L.; Dahe, Q.; Dasgupta, P. Climate Change 2014: Synthesis Report. Contribution of Working Groups I, II and III to the Fifth Assessment Report of the Intergovernmental Panel on Climate Change; IPCC: Geneva, Switzerland, 2014; 151p, ISBN 978-92-9169-143-2.

6. Barth, M.; Rieckmann, M. Academic staff development as a catalyst for curriculum change towards education for sustainable development: An output perspective. J. Clean. Prod. 2012, 26, 28-36. [CrossRef]

7. Corcoran, P.B.; Wals, A.E. Higher education and the challenge of sustainability. Dordr. Kluwer Acad. Publ. 2004, $10,0-306$.

8. Meyer, A. Does education increase pro-environmental behavior? Evidence from Europe. Ecol. Econ. 2015, 116, 108-121. [CrossRef]

9. Lozano, R. Incorporation and institutionalization of SD into universities: Breaking through barriers to change. J. Clean. Prod. 2006, 14, 787-796. [CrossRef]

10. Lukman, R.; Lozano, R.; Vamberger, T.; Krajnc, M. Addressing the attitudinal gap towards improving the environment: A case study from a primary school in Slovenia. J. Clean. Prod. 2013, 48, 93-100. [CrossRef]

11. Park, H.S.; Smith, S.W. Distinctiveness and Influence of Subjective Norms, Personal Descriptive and Injunctive Norms, and Societal Descriptive and Injunctive Norms on Behavioral Intent: A Case of Two Behaviors Critical to Organ Donation. Hum. Commun. Res. 2007, 33, 194-218. [CrossRef]

12. Poortinga, W.; Steg, L.; Vlek, C. Values, environmental concern, and environmental behavior: A study into household energy use Environ. Behav. 2004, 36, 70-93. [CrossRef]

13. Kim, T.; Yun, S. How Will Changes toward Pro-Environmental Behavior Play in Customers' Perceived Value of Environmental Concerns at Coffee Shops? Sustainability 2019, 11, 3816. [CrossRef]

14. Chiang, Y.-T.; Fang, W.-T.; Kaplan, U.; Ng, E. Locus of Control: The Mediation Effect between Emotional Stability and ProEnvironmental Behavior. Sustainability 2019, 11, 820. [CrossRef]

15. Kim, J.J.; Lee, M.J.; Han, H. Smart Hotels and Sustainable Consumer Behavior: Testing the Effect of Perceived Performance, Attitude, and Technology Readiness on Word-of-Mouth. Int. J. Environ. Res. Public Health 2020, 17, 7455. [CrossRef] [PubMed]

16. Han, R.; Cheng, Y. The Influence of Norm Perception on Pro-Environmental Behavior: A Comparison between the Moderating Roles of Traditional Media and Social Media. Int. J. Environ. Res. Public Health 2020, 17, 7164. [CrossRef] [PubMed]

17. Yang, X.; Chen, L.; Wei, L.; Su, Q. Personal and Media Factors Related to Citizens' Pro-environmental Behavioral Intention against Haze in China: A Moderating Analysis of TPB. Int. J. Environ. Res. Public Health 2020, 17, 2314. [CrossRef]

18. Hartmann, P.; Apaolaza, V.; D'Souza, C. The role of psychological empowerment in climate-protective consumer behaviour: An extension of the value-belief-norm framework. Eur. J. Mark. 2018, 52, 392-417. [CrossRef]

19. Islam, T.; Pondicherry University; Chandrasekaran, U. Religiosity and Ecologically Conscious Consumption Behaviour. Asian J. Bus. Res. 2015, 5, 8933. [CrossRef]

20. Zsóka, A.; Szerényi, Z.M.; Széchy, A.; Kocsis, T. Greening due to environmental education? Environmental knowledge, attitudes, consumer behavior and everyday pro-environmental activities of Hungarian high school and university students. J. Clean. Prod. 2013, 48, 126-138. [CrossRef]

21. Rice, G. Pro-environmental Behavior in Egypt: Is there a Role for Islamic Environmental Ethics? J. Bus. Ethics 2006, 65, 373-390. [CrossRef]

22. Jickling, B.; Spork, H. Education for the Environment: A critique. Environ. Educ. Res. 1998, 4, 309-327. [CrossRef]

23. Fien, J. 'Education for the Environment: A critique'-An analysis. Environ. Educ. Res. 2000, 6, 179-192. [CrossRef]

24. Brewer, C. Translating Data into Meaning: Education in Conservation Biology. Conserv. Biol. 2006, 20, 689-691. [CrossRef]

25. Liu, X.; Zou, Y.; Wu, J. Factors influencing public-sphere pro-environmental behavior among Mongolian college students: A test of value-belief-norm theory. Sustainability 2018, 10, 1384. [CrossRef]

26. Diamantopoulos, A.; Schlegelmilch, B.B.; Sinkovics, R.; Bohlen, G.M. Can socio-demographics still play a role in profiling green consumers? A review of the evidence and an empirical investigation. J. Bus. Res. 2003, 56, 465-480. [CrossRef]

27. Ek, K.; Söderholm, P. Norms and economic motivation in the Swedish green electricity market. Ecol. Econ. 2008, 68, 169-182. [CrossRef] 
28. Ayalon, O.; Brody, S.; Shechter, M. Household waste generation, recycling and prevention. In OECD Studies on Environmental Policy and Household Behaviour Greening Household Behaviour Overview from the 2011 Survey: Overview from the 2011 Survey; OECD: Paris, France, 2014; pp. 219-245.

29. Wessells, C.R.; Johnston, R.; Donath, H. Assessing Consumer Preferences for Ecolabeled Seafood: The Influence of Species, Certifier, and Household Attributes. Am. J. Agric. Econ. 1999, 81, 1084-1089. [CrossRef]

30. Grafton, R.Q. Household behaviour and water use. Chap 2014, 5, 149-181. [CrossRef]

31. Diekmann, A.; Preisendörfer, P. Green and greenback: The behavioral effects of environmental attitudes in low-cost and high-cost situations. Ration. Soc. 2003, 15, 441-472. [CrossRef]

32. Kaiser, F.; Ranney, M.; Hartig, T.; Bowler, P.A. Ecological Behavior, Environmental Attitude, and Feelings of Responsibility for the Environment. Eur. Psychol. 1999, 4, 59-74. [CrossRef]

33. Callan, S.J.; Thomas, J.M. Analyzing demand for disposal and recycling services: A systems approach. East. Econ. J. 2006, 32, 221-240.

34. Ferrara, I.; Missios, P. Recycling and Waste Diversion Effectiveness: Evidence from Canada. Environ. Resour. Econ. 2005, 30, 221-238. [CrossRef]

35. Smith, V.K. Does Education Induce People to Improve the Environment? J. Policy Anal. Manag. 1995, 14, 599. [CrossRef]

36. Bellows, A.C.; Onyango, B.; Diamond, A.; Hallman, W. Understanding Consumer Interest in Organics: Production Values vs. Purchasing Behavior. J. Agric. Food Ind. Organ. 2008, 6, 6. [CrossRef]

37. Rana, J.; Paul, J. Consumer behavior and purchase intention for organic food: A review and research agenda. J. Retail. Consum. Serv. 2017, 38, 157-165. [CrossRef]

38. Berk, R.A.; Schulman, D.; McKeever, M.; Freeman, H.E. Measuring the impact of water conservation campaigns in California. Clim. Chang. 1993, 24, 233-248. [CrossRef]

39. Mundaca, L.; Neij, L.; Worrell, E.; McNeil, M.A. Evaluating Energy Efficiency Policies with Energy-Economy Models. Annu. Rev. Environ. Resour. 2010, 35, 305-344. [CrossRef]

40. Rowlands, I.H.; Scott, D.; Parker, P. Consumers and green electricity: Profiling potential purchasers. Bus. Strategy Environ. 2003, 12, 36-48. [CrossRef]

41. De Silva, D.G.; Pownall, R.A.J. Going green: Does it depend on education, gender or income? Appl. Econ. 2013, 46, 573-586. [CrossRef]

42. Xiao, C.; Dunlap, R.E.; Hong, D. The Nature and Bases of Environmental Concern among Chinese Citizens. Soc. Sci. Q. 2012, 94, 672-690. [CrossRef]

43. Torgler, B.; García-Valiñas, M.A. The determinants of individuals' attitudes towards preventing environmental damage. Ecol. Econ. 2007, 63, 536-552. [CrossRef]

44. Mitchell, R.E.; Hodson, C.A. Coping and social support among battered women: An ecological perspective. In Stress, Social Support, and Women; Routledge Publishers: New York, NY, USA, 1986; pp. 153-169.

45. Hobfoll, S.E. Conservation of resources: A new attempt at conceptualizing stress. Am. Psychol. 1989, 44, 513. [CrossRef]

46. Rosenberg, M. Society and the Adolescent Self-Image; Princeton University Press: Princeton, NJ, USA, 2015. [CrossRef]

47. Rosenbaum, M.; Ben-Ari Smira, K. Cognitive and personality factors in the delay of gratification of hemodialysis patients. $J$. Personal. Soc. Psychol. 1986, 51, 357. [CrossRef]

48. Hobfoll, S.E.; Shirom, A. Conservation of resources theory. In Handbook of Organizational Behavior; Golembiewski, R., Ed.; Marcel Dekker: New York, NY, USA, 2000; pp. 57-80.

49. Hobfoll, S.E. The Influence of Culture, Community, and the Nested-Self in the Stress Process: Advancing Conservation of Resources Theory. Appl. Psychol. 2001, 50, 337-421. [CrossRef]

50. Janmaimool, P.; Chudech, S. Effect of Domestic and Global Environmental Events on Environmental Concern and Environmental Responsibility among University Students. Sustainability 2020, 12, 1610. [CrossRef]

51. Laroche, M.; Bergeron, J.; Barbaro-Forleo, G. Targeting consumers who are willing to pay more for environmentally friendly products. J. Consum. Mark. 2001, 18, 503-520. [CrossRef]

52. Han, H.; Hwang, J.; Lee, S. Cognitive, affective, normative, and moral triggers of sustainable intentions among convention-goers. J. Environ. Psychol. 2017, 51, 1-13. [CrossRef]

53. Stern, P.C. New Environmental Theories: Toward a Coherent Theory of Environmentally Significant Behavior. J. Soc. Issues 2000, 56, 407-424. [CrossRef]

54. Lee, K. The Green Purchase Behavior of Hong Kong Young Consumers: The Role of Peer Influence, Local Environmental Involvement, and Concrete Environmental Knowledge. J. Int. Consum. Mark. 2010, 23, 21-44. [CrossRef]

55. Mostafa, M.M. A hierarchical analysis of the green consciousness of the Egyptian consumer. Psychol. Mark. 2007, 24, 445-473. [CrossRef]

56. Clark, C.F.; Kotchen, M.J.; Moore, M.R. Internal and external influences on pro-environmental behavior: Participation in a green electricity program. J. Environ. Psychol. 2003, 23, 237-246. [CrossRef]

57. Zhu, H.; Wong, N.; Huang, M. Does relationship matter? How social distance influences perceptions of responsibility on anthropomorphized environmental objects and conservation intentions. J. Bus. Res. 2019, 95, 62-70. [CrossRef]

58. Barr, S. Strategies for sustainability: Citizens and responsible environmental behaviour. Area 2003, 35, 227-240. [CrossRef] 
59. Kaiser, F.; Shimoda, T.A. RESPONSIBILITY AS A PREDICTOR OF ECOLOGICAL BEHAVIOUR. J. Environ. Psychol. 1999, 19, 243-253. [CrossRef]

60. Cerveny, L.K.; Miller, A.; Gende, S. Sustainable Cruise Tourism in Marine World Heritage Sites. Sustainability 2020, $12,611$. [CrossRef]

61. Dolnicar, S.; Leisch, F. Selective marketing for environmentally sustainable tourism. Tour. Manag. 2008, 29, 672-680. [CrossRef]

62. Hobfoll, S.E. Conservation of resource caravans and engaged settings. J. Occup. Organ. Psychol. 2011, 84, 116-122. [CrossRef]

63. Pfeifer, J.H.; Berkman, E.T. The Development of Self and Identity in Adolescence: Neural Evidence and Implications for a Value-Based Choice Perspective on Motivated Behavior. Child Dev. Perspect. 2018, 12, 158-164. [CrossRef]

64. Rehman, A.; Shabbir, M.S. The relationship between religiosity and new product adoption. J. Islam. Mark. 2010, 1, 63-69. [CrossRef]

65. Kollmuss, A.; Agyeman, J. Mind the Gap: Why do people act environmentally and what are the barriers to pro-environmental behavior? Environ. Educ. Res. 2002, 8, 239-260. [CrossRef]

66. Fam, K.-S.; Waller, D.S.; Erdogan, B.Z. The influence of religion on attitudes towards the advertising of controversial products. Eur. J. Mark. 2004, 38, 537-555. [CrossRef]

67. Alam, S.S.; Mohd, R.; Hisham, B. Is religiosity an important determinant on Muslim consumer behaviour in Malaysia? J. Islam. Mark. 2011, 2, 83-96. [CrossRef]

68. Eid, R.; El-Gohary, H. The role of Islamic religiosity on the relationship between perceived value and tourist satisfaction. Tour. Manag. 2015, 46, 477-488. [CrossRef]

69. Shukor, S.A.; Jamal, A. Developing scales for measuring religiosity in the context of consumer research. Middle East J. Sci. Res. 2013, 13, 69-74.

70. Razzaq, A.; Ansari, N.Y.; Razzaq, Z.; Awan, H.M. The Impact of Fashion Involvement and Pro-Environmental Attitude on Sustainable Clothing Consumption: The Moderating Role of Islamic Religiosity. SAGE Open 2018, 8, 2158244018774611. [CrossRef]

71. Gardner, G. Invoking the Spirit: Religion and Spirituality in the Quest for A Sustainable World; Worldwatch Paper; Worldwatch Institute: Washington, DC, USA, 2002.

72. Ghazali, E.M.; Mutum, D.S.; Ariswibowo, N. Impact of religious values and habit on an extended green purchase behaviour model. Int. J. Consum. Stud. 2018, 42, 639-654. [CrossRef]

73. Akhtar, R.; Sultana, S.; Masud, M.M.; Jafrin, N.; Al-Mamun, A. Consumers' environmental ethics, willingness, and green consumerism between lower and higher income groups. Resour. Conserv. Recycl. 2021, 168, 105274. [CrossRef]

74. Djallela, L.; bin Abdul Rahimb, A.K. A Conceptual Study on Consumer Needs from an Islamic Marketing Perspective. Int. J. Innov. Creat. Chang. 2020, 10, 571-591.

75. Charag, A.H.; Fazili, A.I.; Bashir, I. Determinants of consumer's readiness to adopt Islamic banking in Kashmir. J. Islam. Mark. 2019, 11, 1125-1154. [CrossRef]

76. Koehrsen, J. Muslims and climate change: How Islam, Muslim organizations, and religious leaders influence climate change perceptions and mitigation activities. Wiley Interdiscip. Rev. Clim. Chang. 2021, 12, e702. [CrossRef]

77. Taylor, B.; Van Wieren, G.; Zaleha, B. The Greening of Religion Hypothesis (Part Two): Assessing the Data from Lynn White, Jr, to Pope Francis. J. Study Relig. Nat. Cult. 2016, 10, 306-378. [CrossRef]

78. Abdullah, Y.A. The Holy Qur'an; Abdullah, Y.A., Translator; Wordsworth Editions Ltd.: Ware, UK, 2000.

79. Yu, T.-Y.; Chao, C.-M. Understanding Taiwanese undergraduate students' pro-environmental behavioral intention towards green products in the fight against climate change. J. Clean. Prod. 2017, 161, 390-402. [CrossRef]

80. Pérez-Rodríguez, U.; Varela-Losada, M.; Lires, F.J. Álvarez; Vega-Marcote, P. Attitudes of preservice teachers: Design and validation of an attitude scale toward environmental education. J. Clean. Prod. 2017, 164, 634-641. [CrossRef]

81. Varela-Candamio, L.; Novo-Corti, I.; García-Álvarez, M.T. The importance of environmental education in the determinants of green behavior: A meta-analysis approach. J. Clean. Prod. 2018, 170, 1565-1578. [CrossRef]

82. Wang, P.; Liu, Q.; Qi, Y. Factors influencing sustainable consumption behaviors: A survey of the rural residents in China. J. Clean. Prod. 2014, 63, 152-165. [CrossRef]

83. Liobikienè, G.; Poškus, M.S. The Importance of Environmental Knowledge for Private and Public Sphere Pro-Environmental Behavior: Modifying the Value-Belief-Norm Theory. Sustainability 2019, 11, 3324. [CrossRef]

84. Plante, T.G. The Santa Clara Strength of Religious Faith Questionnaire (SCSRFQ): A Brief, Nondenominational, and Multicultural Assessment Tool. In Assessing Spirituality in a Diverse World; Springer: Berlin/Heidelberg, Germany, 2021; pp. 445-466.

85. Kaiser, F.; Doka, G.; Hofstetter, P.; Ranney, M.A. Ecological behavior and its environmental consequences: A life cycle assessment of a self-report measure. J. Environ. Psychol. 2003, 23, 11-20. [CrossRef]

86. Begum, A.; Jingwei, L.; Haider, M.; Ajmal, M.; Khan, S.; Han, H. Impact of Environmental Moral Education on Pro-Environmental Behaviour: Do Psychological Empowerment and Islamic Religiosity Matter? Int. J. Environ. Res. Public Health 2021, $18,1604$. [CrossRef]

87. Spector, P.E.; Fox, S.; Penney, L.M.; Bruursema, K.; Goh, A.; Kessler, S. The dimensionality of counterproductivity: Are all counterproductive behaviors created equal? J. Vocat. Behav. 2006, 68, 446-460. [CrossRef]

88. Podsakoff, P.M.; MacKenzie, S.B.; Lee, J.-Y.; Podsakoff, N.P. Common method biases in behavioral research: A critical review of the literature and recommended remedies. J. Appl. Psychol. 2003, 88, 879-903. [CrossRef] 
89. Anderson, J.C.; Gerbing, D.W. Structural equation modeling in practice: A review and recommended two-step approach. Psychol. Bull. 1988, 103, 411-423. [CrossRef]

90. Kline, R.B. Response to Leslie Hayduk's Review of Principles and Practice of Structural Equation Modeling. Can. Stud. Popul. [ARCHIVES] 2018, 45, 188-195. [CrossRef]

91. Anning-Dorson, T. How much and when to innovate. Eur. J. Innov. Manag. 2017, 20, 599-619. [CrossRef]

92. Fornell, C.; Larcker, D.F. Evaluating Structural Equation Models with Unobservable Variables and Measurement Error. J. Mark. Res. 1981, 18, 39. [CrossRef]

93. Schumacker, R.E.; Lomax, R.G. A Beginner's Guide to Structural Equation Modeling; Lawrence Erlbaum Associates: Mahwah, NJ, USA, 2004.

94. Otto, S.; Pensini, P. Nature-based environmental education of children: Environmental knowledge and connectedness to nature, together, are related to ecological behaviour. Glob. Environ. Chang. 2017, 47, 88-94. [CrossRef]

95. Ballantyne, R.; Packer, J. Nature-based Excursions: School Students' Perceptions of Learning in Natural Environments. Int. Res. Geogr. Environ. Educ. 2002, 11, 218-236. [CrossRef]

96. Monroe, M.C. Two avenues for encouraging conservation behaviors. Hum. Ecol. Rev. 2003, 10, 113-125.

97. Yue, B.; Sheng, G.; She, S.; Xu, J. Impact of Consumer Environmental Responsibility on Green Consumption Behavior in China: The Role of Environmental Concern and Price Sensitivity. Sustainability 2020, 12, 2074. [CrossRef]

98. Shah, S.; Ahmed, U.; Ismail, A.; Mozammel, S. Going Intellectually Green: Exploring the Nexus between Green Intellectual Capital, Environmental Responsibility, and Environmental Concern towards Environmental Performance. Sustainability 2021, 13, 6257. [CrossRef]

99. Mohammad, B.A.M.A.-H.; Som, A.P.M. An Analysis of Push and Pull Travel Motivations of Foreign Tourists to Jordan. Int. J. Bus. Manag. 2010, 5, 41. [CrossRef]

100. Galinsky, A.D.; Gruenfeld, D.H.; Magee, J.C. From power to action. J. Personal. Soc. Psychol. 2003, 85, 453. [CrossRef] [PubMed]

101. Poškus, M.S. Investigating pro-Environmental Behaviors of Lithuanian University Students. Curr. Psychol. 2018, 37, 225-233. [CrossRef]

102. Carfora, V.; Caso, D.; Sparks, P.; Conner, M. Moderating effects of pro-environmental self-identity on pro-environmental intentions and behaviour: A multi-behaviour study. J. Environ. Psychol. 2017, 53, 92-99. [CrossRef]

103. Fang, W.-T.; Ng, E.; Zhan, Y.-S. Determinants of Pro-Environmental Behavior among Young and Older Farmers in Taiwan. Sustainability 2018, 10, 2186. [CrossRef]

104. Markle, G. Understanding Pro-Environmental Behavior in the US: Insights from Grid-Group Cultural Theory and Cognitive Sociology. Sustainability 2019, 11, 532. [CrossRef] 